\title{
Kuidas mõtestavad ekspositsiooni koostajad auditooriumide kaasamist? Kujuteldavad auditooriumid ja kaasamisviisid Tartu Ülikooli loodusmuuseumi uue püsiekspositsiooni loomisel
}

\author{
Krista Lepik \\ Reet Mägi \\ Pille Pruulmann-Vengerfeldt
}

\section{Sissejuhatus}

ERMi aastaraamatu lugejatele on muuseumide sihtrühmade ja auditooriumidega seotud teemasid tutvustatud oige mitmel korral (Runnel ja Pruulmann-Vengerfeldt 2012; Teppor ja Aljas 2013; Lotina 2014; Runnel, Lepik, Pruulmann-Vengerfeldt 2014) ning peamiselt sellisest vaatenurgast, kus auditooriumide tundmine, nende kaasamine ja nendega arvestamine on muuseumidele järjest olulisem. Ka värske muuseumide ja raamatukogude kasutajate ja mittekasutajate uurimus (Muuseumide ja raamatukogude ... 2018) näitas, et sihtrühmade kaasamise arutelud meeldejääva ja tähendusrikka muuseumikogemuse kujundamiseks ei ole oma aktuaalsust kaotanud - muuseumikülastajate osakaal Eesti elanikkonnas on ligikaudu 60\%. Ent kuidas mõtestavad auditooriume ekspositsiooni tegijad? Meie artikli eesmärk ongi uurida Tartu Ülikooli loodusmuuseumi uue püsiekspositsiooni näitel, kuidas kujundavad ekspositsioonide koostajad erinevaid auditooriume ning nende kaasamise võimalusi ekspositsiooni loomise käigus.

Analüüsi valmimiseks tegime intervjuusid loodusmuuseumi püsiekspositsiooni sisu koostajatega - kuraatoritega - ning Eden Litti (2012) kujuteldavate auditooriumide kontseptsioonile tuginedes 
uurisime, kuidas nad kavandasid auditooriumide kõnetamist ekspositsiooni ja sellega seotud tegevuste kaudu. Intervjuude analüüsimise meetodiks valisime konstruktivistliku põhistatud teooria (Charmaz 2014). Kujuteldavate auditooriumide lähenemisviis on ekspositsioonide loomisel ka praktikas rakendatav, sest otsused, kuidas ja milliseid sõnumeid tegelikule auditooriumile edastatakse, võivad olla tugevalt mõjutatud kujuteldud auditooriumidest (Litt 2012: 333). Kuna ekspositsiooni loomine on ressursimahukas ja see on pärast valmimist raskesti muudetav, on vajalik, et muuseumi füüsilise keskkonna loojad oleksid oma kujutletud auditooriumidest teadlikud ja püüaksid seda teadmist kasutada.

Tartu Ülikooli loodusmuuseum on rohkem kui kahesajaaastase tegevuse jooksul olnud järjepidevalt ülikooli teadus- ja õppetöö üksuseks, kuid ekspositsioonide ning haridustegevusega erineval määral ja viisil suunatud ka ülikoolivälistele auditooriumidele. Nüüdne uus ekspositsioon, mille loomise eesmärk oli suurendada ühiskonnas teadlikkust loodus- ja keskkonnateemadest, keskendub sihipäraselt ainult ülikoolivälistele auditooriumidele. Ekspositsioon valmis aastail 2010-2016 Euroopa Liidu toetusel.

\section{Teoreetilised lähtekohad: ekspositsiooni kujuteldavad auditooriumid ja nende kaasamisviisid}

Meedia- ja kommunikatsiooniuuringute lähenemisviisidest tulenevalt peame auditooriumide all silmas kõiki, kellega muuseum suhtleb (Runnel, Lepik ja Pruulmann-Vengerfeldt 2014): see mõiste hõlmab külastajaid, kliente, sidusrühmi, osalejaid ning teisi spetsiifilisi suhestumise kontekste (Lotina 2016: 12). Ka kujuteldavate auditooriumide kontseptsioon pärineb meedia- ja kommunikatsiooniuuringute valdkonnast, kus seda on rakendatud nii sotsiaalmeedia (Marwick ja boyd 2010; Litt 2012; Murumaa-Mengel 2017) kui ka traditsioonilise ja ristmeedia protsesside uurimisel (Nanì 2018). Pidades silmas, et ka muuseumi ekspositsioonil on sõnum (Runnel 2014), laiendame kujuteldavate auditooriumide lähenemisviisi muuseumi ekspositsioonile ja sellega seotud tegevustele ning Littile (2012) tuginedes käsitleme kujuteldavaid auditooriume „nende inimeste vaimse kontseptualiseerimisena, kellega me suhtleme" (samas: 331). Kujuteldavaid auditooriume muuseumide kontekstis on käsitlenud ka mõned varasemad tööd - nii sisuloojate (O’Neill 2008; Smart 2008) kui ka külastajate kaudu, kes muuseumi tegevustes osaledes suhestuvad „kujuteldava kogukonnaga“ (Coghlan 2018). 
Auditooriumide kujutlemise muudab keerukaks nende heterogeensus ja ebastabiilsus, auditooriumide kujutlemise protsessi aga mõjutavad mitmesugused tegurid (Litt 2012), mida kujutame joonisel 1. Litt (2012) jaotab auditooriumide kujutlemist mõjutavad tegurid Anthony Giddensi strukturatsiooniteooriast (1984) lähtudes vastastikku tihedalt seotud struktuurseteks ja agentseteks teguriteks. Giddensi järgi (1984: xxxi) moodustavad struktuuri reeglid ja ressursid, mis mõjutavad ka muuseumi ekspositsiooni koostamist, samas kui ekspositsiooni on loonud kuraatorid - Giddensi mõistes „agendid“ ehk toimijad (samas). Ekspositsiooni kavandamisel võivad struktuursed komponendid (ruumilised, finantsilised ja institutsionaalsed auditooriumi kujutlemise dimensioonid) tähendada nii piiranguid kui ka uusi võimalusi. Samasugust mõju avaldavad ekspositsioonile agentsuse poolelt kuraatorite individuaalsed kogemused, ootused, motivatsioon ja oskused. Kõik need tegurid mõjutavad kuraatoreid auditooriumide kujutlemisel, mis omakorda vormib tulevastele auditooriumidele suunatud tegevusi (Litt 2012: 334).

Auditooriumide kujutlemist suunatakse küsimustega auditooriumide kaasamise viisidest. Alice E. Marwick ja danah boyd (2010: 9) järeldavad, et sotsiaalmeedia loojate kujutletud auditooriumid varieeruvad sõltuvalt sotsiaalmeedia kasutamisest kas „vahendamise meediumina, turunduskanalina, päevikuna, sotsiaalse platvormina või uudiste allikana". Ka Litt (2012: 339) rõhutab, et auditooriumide kujutlemist mõjutab kontekst, missugusel eesmärgil sotsiaalmeediat kasutatakse. Uurides, millist rolli nähakse ekspositsioonil kujuteldavatest kasutajatest lähtudes, näeme, et ettekujutus auditooriumidest on seotud küsimusega, mida saavad inimesed ekspositsioonis teha ja missugust kaasatust nende tegevused toetavad.

Teine oluline kontseptsioon meie uuringus on kaasamine, mis on eelnevalt juba teoreetiliselt määratletud ja kategoriseeritud (Dahlgren 2006; MTM London 2010) ning tuttav ka muuseumiuuringutest. Siin artiklis tugineme varasematele uuringutele muuseumide tegevuste ja auditooriumide omavahelisest suhestumisest (Lotina ja Lepik 2015; Lotina 2016). Toetume Linda Lotina pakutud definitsioonile, mille järgi kaasamine on „kahesuunaline protsess, mis kombineerib muuseumi ja aktiivse auditooriumi tegevusi, vastates kaasatud osapoolte stiimulitele ja käivitades muuseumi tegevusi eesmärgiga parandada muuseumitööd, tugevdada auditooriumide kogemusi või muuta midagi ühiskonnas laiemalt" (Lotina 2016: 35). Muuseumi kaasamisviisidena mõistame tegevusi, mis vastavad muuseumi eesmärkidele, kutsuvad auditooriumides esile teatud reaktsioone või innustavad erinevatel viisidel osalema muuseumi tegevustes (Lotina ja Lepik 2015: 127; Lotina 2016: 35). 
Meie uurimusele olid juhtlõngadeks Lotina määratletud muuseumide kaasamisviisid: „informeerimine“, mis tähendab otseselt hariduslikke tegevusi; „turundus ja reklaam“, mis hõlmab muuseumi külastama kutsuvaid tegevusi; „konsulteerimine“, mis ärgitab kasutajaid arutlema ja andma tagasisidet ning kaasab „kogukonna kollektiivse teadmuse“; „koostöö“, milles külastajatel on aktiivne roll näiteks annetajana, vabatahtlikuna või sisuloojana; ,kontakt osalejatega/auditooriumidega", mis aitab muuseumil säilitada ja tugevdada muuseumi ning auditooriumide sidemeid; „kontakt sidusrühmadega“, mis väljendab muuseumi rolli teenida sidusrühmade eesmärke; „kontakt professionaalidega“, kus muuseumil on erialase koostööpartneri roll (Lotina 2016: 59-61). Kuna uurimuse käigus tõstatus küsimus, kas Lotina kirjeldatud kaasamisviisid on rakendatavad ja ammendavad nende väljatöötamise baasiga võrreldes teist tüüpi muuseumis ja konkreetses muuseumikeskkonnas - loodusmuuseumis ja püsiekspositsioonis -, arvestame Lotina kaasamisviiside süsteemiga, kui tugineme oma andmetele.

Pidades silmas Giddensi strukturatsiooniteooriat (1984), mis raamistab nii Litti kujuteldavate auditooriumide kontseptsiooni (2012) kui ka Lotina kaasamisviiside määratlemist (2016), võtame uurimuse teoreetilise vaate kokku (joonis 1). Joonis 1 näitab auditooriumide kujutlemise struktuurseid ja agentseid tegureid, mis tegevustega seotud kaasamisviiside kujutlemise kaudu mõjutavad tegelike auditooriumide kaasatust.

Uurimuses analüüsisime intervjuusid, et välja selgitada, millised struktureerivad ja agentsusele osutavad tegurid kuraatoreid püsiekspositsiooni loomisel mõjutasid ning kuidas nad kaasavaid tegevusi ja kaasamisviise ette kujutasid. Selline mudeldamine võimaldab näituste tegijatel oma tegevuse printsiipe paremini selgitada, lisaks võib selle abil oma visioonide analüüsimine olla ekspositsioonimeeskonnale kasulik ühise taustsüsteemi loomiseks.

Et mõista, kuidas ekspositsiooni koostajad (kuraatorid) kujundavad auditooriume ja nende kaasamist ekspositsioonidega seotud tegevustes, püstitame järgmised uurimisküsimused:

1. Keda pidasid kuraatorid silmas püsiekspositsiooni kujuteldavate auditooriumidena?

2. Missugused tegurid kujundasid kuraatoritel auditooriumide konstrueerimise protsessi?

3. Kuidas kujutasid kuraatorid ette püsiekspositsiooni külastavate auditooriumide kaasamist muuseumi poolt? 


\section{Struktuur}

Sotsiaalsed rollid

Sotsiaalsed

kontekstid

Aktiivne auditoorium

Koha/teenuste

tunnused

\section{Agentsus}

Sotsiaalsed oskused

Motivatsioon

Interneti kasutamise

oskused
Kujuteldavad

kaasavad tegevused

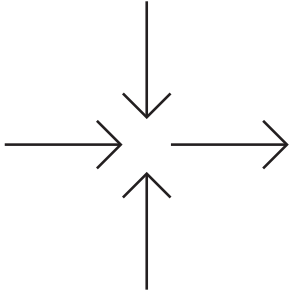

Tegelikud

auditooriumid

Tegevuste ja

kaasatusega
Kujuteldavad

kaasamisviisid

Joonis 1. Litti (2012) auditooriumide kujutlemise mudeli edasiarendus, kuhu lisasime täiendusena kujuteldavad kaasamistegevused ja -viisid Lotinalt (2016).

\section{Meetod: konstruktivistlik põhistatud teooria}

Artikkel tugineb ekspositsiooni kaheteistkümne kuraatoriga tehtud poolstruktureeritud intervjuude kvalitatiivsel analüüsil, mis lähtub Kathy Charmazi välja arendatud konstruktivistlikust põhistatud teooriast (Charmaz 2014). Nimetatud lähenemisviis sobis kogutud andmete, uurimisobjekti ja eesmärgiga arendada kujuteldavate auditooriumide kontseptsiooni muuseumide kontekstis, sest lubas paindlikkust intervjuude läbiviimisel ning võimaldas andmetest lähtuvas analüüsis arvestada nii teoreetilise taustaga - kujuteldavate auditooriumide kontseptsiooniga (Litt 2012) - kui ka varasemate uurimistulemustega muuseumide kaasamisviisidest (Lotina 2016).

Intervjuud toimusid 2016. aasta esimesel poolel. Et koguda võimalikult rikkalik andmestik, valisime ligikaudu neljakümne kuraatori seast intervjueeritavad, kes olid mõne ekspositsiooni teema koostajaks või vastutasid mõne suurema terviku eest. Enamik intervjueeritutest 
osales loomingulises protsessis alates ekspositsiooni esialgsest kavandamisest, kuid mõned olid liitunud ka edasise töö käigus. Küsitletud kuraatorite hulgas oli nii Tartu Ülikooli loodusmuuseumi töötajaid, kolleege teistest ülikooli üksustest kui ka spetsialiste väljastpoolt Tartu Ülikooli. Valimis oli erineva kogemuse ja erialase taustaga inimesi: viis neist (sealhulgas kaks muuseumi töötajana) oli õpetanud kooliõpilasi või üliõpilasi eelmises ekspositsioonis ning kolm olid teadlased. Valimisse kaasatud kuraatorite erialane taust kattis ekspositsiooni koostamisele kaasatud põhilised valdkonnad kaasasime viis bioloogi, kolm geoloogi, kaks semiootikut, ühe ajaloolase ja ühe infotehnoloogi. Varasem näituse koostamise kogemus oli neljal intervjueeritaval. Sõnasõnalised väljavõtted intervjuudest on väikese meeskonna liikmete privaatsuse kaitsmiseks anonüümsed.

Vastavalt poolstruktureeritud intervjuude läbiviimise printsiibile kasutasime küsimustikku, mida muutsime paindlikult, näiteks lisasime küsimusi ja muutsime nende järjekorda, kui oli vaja teemasse enam süveneda või tagada mõtteavalduse suurem selgus (Lepik jt 2014). Transkribeeritud intervjuude analüüs järgis konstruktivistliku põhistatud teooria meetodi printsiipe. Andmed kodeerisime mitmes seotud etapis: esialgsel kodeerimisel avatud koodidena ja järgneval fokusseeritud kodeerimisel üldistatud kategooriakoodidena (Charmaz 2014). Tulemused valmisid mitmes etapis läbikirjutuste põhjal, mille käigus pöördusime ka korduvalt tagasi algandmete - intervjuutekstide - poole (samas). Analüüsis arvestasime kujuteldavate auditooriumide teoreetilise raamistikuga (Litt 2012) ning Lotina väljapakutud muuseumide kaasamisviisidega (2016).

Artikli koostajatel on teineteist toetavad ja vastastikku peegeldavad rollid. Arvesse tuli võtta siseringi uurimuse (insider research) dilemmasid, mis mõjutasid eelkõige ekspositsiooni uuendamise projektijuhina töötanud autori osalust. Intervjuud tegi esimene autor, kes ei olnud osalenud ekspositsiooni koostamisel. Artikli teine autor ei osalenud intervjuudel, et vältida rollide konflikti ja võimaldada intervjueeritavatel oma ideid detailselt kirjeldada, kuid tundes konteksti, teostas ta enamiku andmeanalüüsist. Uurimuse puhul võeti arvesse nii võimalikke riske (näiteks eetika, anonüümsuse ja suhetega seotud valikuid) kui ka eeliseid, nagu ligipääsu uuritavale teemale ja konteksti tundmist (Atkins ja Wallace 2012). Riske tasakaalustasid teadlikkus uurijate rollidest ning uurimuse teoreetiline ja metoodiline selgus, mida rõhutavad oma soovitustes ka Atkins ja Wallace (2012). Uurija seotus uurimisobjektiga haakub hästi konstruktivistliku põhistatud teooriaga, mis toetab uurijate osalust andmete konstrueerimisel ja tõlgendamisel (Charmaz 2014: 14). 


\section{Tulemused: kujuteldavad auditooriumid ja kaasamisviisid}

Esitame tulemused vastavalt uurimisküsimustele:

- esiteks tutvustame, missuguseid auditooriume kujutleti;

- teiseks anname ülevaate teguritest, mis mõjutasid kuraatoreid

konstrueerima ja kaasama ekspositsiooni auditooriume;

- kolmandaks tutvustame kuraatorite visioone ekspositsiooniga seotud auditooriumide kaasamisviisidest.

\section{Loodusmuuseumi püsiekspositsiooni kujuteldavad auditooriumid}

Kuraatorite kirjeldatud auditooriume analüüsides selgus, et need jagunesid kahte põhirühma: indiviidid ja organisatsioonid. Indiviidide hulka kuulusid nii üksikkülastajad kui ka grupid, keda kirjeldati isikutena; organisatsioonidel oli muuseumiga koostöö- või teatud vastastikuse sõltuvuse suhe. Mõlemad auditooriumide põhirühmad koosnesid mitmest täpsemalt määratletud alamrühmast.

Võtame joonisel kokku indiviididest auditooriumide kirjeldamise (joonis 2). Kuraatorid nimetasid nii isikute kui ka nende rollidega seotud tunnuseid, kusjuures iga isik võis omada mitmeid omadusi ja kuuluda samaaegselt erinevatesse auditooriumidesse. Isikutega seotud tunnused olid demograafilised (vanus, geograafiline päritolu), kuid lisaks mainiti ka mitmete keelte valdamist, varieeruvaid huvisid (oluliseks peeti loodushuvi või selle puudumist) ning eelistust informatsiooni modaalsustele (tekstid, objektid või videod). Auditooriumirühmade kirjeldamise ühe vaatepunktina peeti silmas ka muuseumiga suhestumise motivatsiooni, mis kuraatorite vastustes katavad John F. Falki esitatud muuseumikülastajate spektri: nende hulgas on inimesed, keda toob muuseumisse huvi, ehk „avastajad“ (Explorers); on neid, keda suunab sotsiaalne motivatsioon näiteks oma lastele kasuliku ajaviite pakkumiseks - „abistajad“ (Facilitators); on erialase huviga „professionaale/amatööre“ (Professional/ Hobbyist), vaimsust otsivad „kogemuste otsijad“ (Experience Seekers), loodusteadusliku süstemaatilise korrastatuse nautijad ehk „laadijad“ (Rechargers), kohusetunde tõttu külastajad ehk ,aupaklikud palverändurid“ (Respectful Pilgrims), aga ka lapsepõlve armsa külastuskoha meenutajad ehk „läheduse otsijad“(Affinity Seekers) (Falk 2011; kategooriate eestikeelsed nimetused Runnel, Lepik ja PruulmannVengerfeldt 2014). 


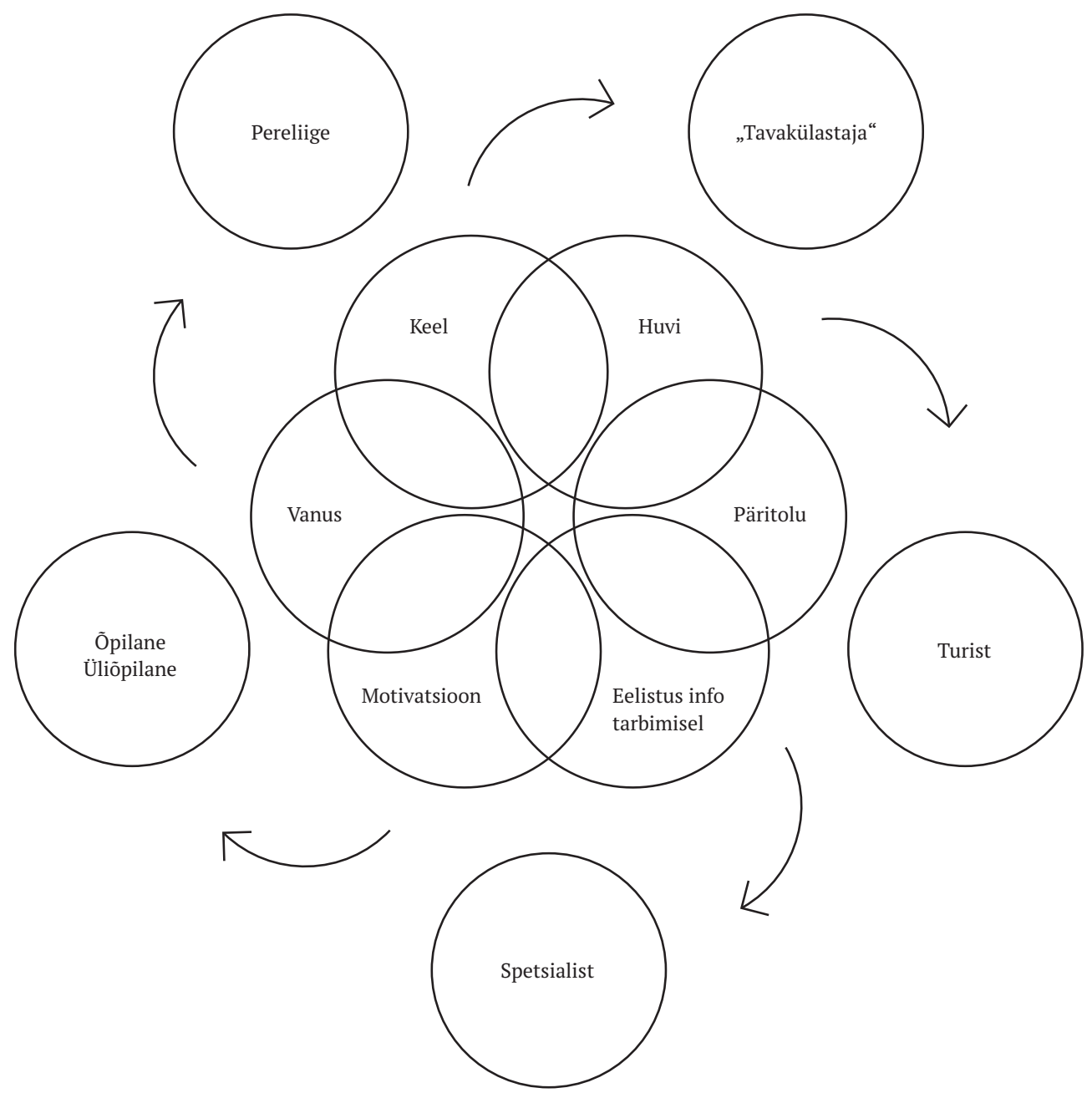

Joonis 2. Indiviididest kujuteldavate auditooriumide struktuur. Iga indiviid on kombinatsioon isikulistest (sisering) ja rolli (välisring) omadustest.

Kuraatorid kirjeldasid ka indiviidide auditooriumirühma omadusi, mis põhinesid ekspositsiooni külastamise eesmärgiga seotud rollidel. Enim mainitud grupp oli ootuspäraselt õpilased - see langeb kokku ka ekspositsiooni uuendamise kokkulepitud põhieesmärgiga luua õpikeskkond mitteformaalsele keskkonnaharidusele. Kuraatorid selgitasid, et õpilased võivad külastada muuseumi õpetajatega, individuaalselt või muuseumitöötajate juhendamisel, tulla eri tüüpi koolidest, olla täiskasvanud õppijad või erivajadustega õpilased. 
Üliõpilasi, kes olid eelmiste ekspositsioonide põhikülastajate seas, ei nähtud nüüd enam auditooriumina, kelle vajadustest lähtuda seetõttu vähenes võrreldes eelmiste ekspositsioonidega eksponeeritud eksemplaride arv ning uues ekspositsioonis anti rohkem ruumi selgitustele. Siiski mainisid kuraatorid, et mõned eriti rikkaliku kollektsiooniga teemad pakuvad huvi ka tudengitele.

Rollil põhinev jaotus sisaldas ka kategooriat „tavakülastaja“, kes ei tulnud õppetööle ega ole spetsialist. Nn tavakülastaja võib olla näiteks pere (lapsevanemad või lapsed), aga ka turist. Kui peresid nähti ühe põhilise auditooriumina juba varasemas ekspositsioonis, siis turiste peeti uueks grupiks. Professionaalide grupis nimetati konverentsikülalisi, välisteadlasi ning kuraatorite kolleege oma ülikoolist, kusjuures märgiti, et loodusteaduste spetsialiseerumise tõttu on teadlased ühtlasi ka tavakülastajad ning professionaalid ainult oma kitsamal erialal. Kui kontekstiks oli vajadus sobitada ekspositsioon korraga paljudele auditooriumirühmadele, leidis mainimist nn katusrühm „kõik külastajad“, keda nimetati ka „kõik inimesed“.

Teine põhiline auditooriumide grupp lisaks indiviididele oli organisatsioonid, mille hulgas nimetati enim koole, ülikoole ja akadeemilisi kogukondi, aga ka projekti rahastanud asutust. Kõik organisatsioonidest auditooriumid omasid rolli kuraatorite tööd mõjutavate teguritena, mida kirjeldame allpool.

Koole nägid kuraatorid sõltuvalt oma taustast ja käsitletava teema kontekstist nii võrdväärsete koostööpartnerite kui ka klientidena, kelle vajadustele peab ekspositsioon vastama ning kellele pakutavaid teenuseid peab ekspositsioon toetama. Seejuures räägiti koolidest enamasti läbi õpetajate kui võtmeisikute võimaldajate -, kes muuseumikülastuse otsustavad. Samuti pidasid kuraatorid auditooriumina silmas oma ülikooli ja struktuuriüksust ning akadeemilist kogukonda üldiselt. Projekti rahastajat mainisid kuraatorid kas otse, rääkides kohustuslikest projekti tingimustest, või kaudsemalt rahastaja ootuste kaudu, millega tuli arvestada.

Sarnaselt indiviidide rühmale oli ka organisatsioonide seas kõiki auditooriume hõlmav katusgrupp „kogu ühiskond“, mille kontekst oli muuseumi missioon tõsta ühiskonna loodus- ja keskkonnaalast teadlikkust, väärtustada loodushoidu ja vastutustundlikku loodusressursside tarbimist ning arendada teaduspõhist maailmavaadet. 


\section{Kujuteldavate auditooriumide konstrueerimist mõjutavad tegurid}

Ekspositsiooni koostajate ettekujutust auditooriumidest mõjutasid kahte tü̈̈pi tegurid: struktuursed tegurid, milleks olid kuraatoritele esitatavad nõudmised ja tingimused, ja agentsed tegurid, mis seisnesid kuraatorite endi omadustes ja otsustes.

Struktuursete tegurite seas olid olulisel kohal ekspositsiooni loomist rahastanud Euroopa Liidu toetusprojekti nõuded, et ekspositsioon oleks suunatud mitteformaalse keskkonnahariduse õpikeskkonna loomiseks ning eelkõige kooliõpilastele. Kuraatorid, kes ise ei olnud seotud projekti koostamisega, kirjeldasid rahastaja ootusi kammitseva kohustustena:

Et oleks ka konkreetselt seotud õppeprorgammidega, et seda teemat käsitletakse, et kui seal on ... mingid teemad, mida üheski õpikus ei ole, siis rahastaja oleks öelnud ilmselt, et oot-oot, siin on nü̈̈d ilmselt midagi teil viltu, et me ei tahtnud sellist ekspositsiooni ... sihtrühm oli juba selle projekti enda taotluses määratud... See oli see, mille jaoks KIK raha tegelikult andis. Me olime otseselt rahastaja poolt seatud tingimustega kammitsetud.

Ekspositsiooni koostamine oli seotud ka ruumiliste tingimustega, mida kuraatorid käsitlesid piiranguna. Üks kuraatoritest, kes tunnistas, et teda häirivad ülekuhjatud muuseumid, kirjeldas, kuidas napil pinnal ei olnud võimalik luua külastajatele meeldivat keskkonda:

See ruum, tegelikult, mis oli kasutada, on loodusmuuseumi jaoks selgelt väike ... lihtsalt see, et seda vitriinimaterjali kõike on liiga palju. Kui see oleks laiali jaotatud kaks korda suuremale pinnale, noh, kindlasti oleks hoopis-hoopis parem tunne seal ka külastajana käia.

\section{Ülikooli teadustööle tuginemist nimetati ekspositsiooni põhialuse jätkumisena, mistõttu jätkub ka uues ekspositsioonis sama, väljakujunenud joon, kuid nüüd siiski mitmekesisemaid auditooriume arvestavalt:}

Sisuliselt ta oli ikkagi ülikooli loodusloolise tegevuse väljund või pilt ühiskonnale, millega ülikooli loodusteadlased juba ülikooli algusaegadest peale on tegelenud ... Ega ta põhimõtteliselt ei muutugi, aga natukene läheb nü̈̈d avaramaks ühiskonna poole vaadates. 
Mainiti, et ekspositsiooni tegemist mõjutas ka muuseumi eesmärk säilitada ja arendada muuseumi positsiooni koolidele suunatud mitteformaalsel haridusteenuste maastikul. Seejuures peeti vajalikuks vastata õpetajate ootustele:

Aga meid siin toetab see, et me oleme juba pildile saanud kümne aasta jooksul ... ja siis uurid nende vajadusi, noh, me arvestame nende tagasisidet siiski, et mida on rohkem vaja, mida rohkem tahetakse ja muud ka, mida me arvame, et hästi sobiks, siis püüame seda ka pakkuda.

Agentsetest teguritest mõjutasid kuraatoreid nende eriala ja oskused, aga ka kogemused ja motivatsioon ning varasem muuseumikogemus nii tööalaselt kui ka külastajana. Kuna kuraatorid olid ekspositsiooni koostamisele valitud oskustest lähtudes, oli auditooriumide ootuste kujutlemine oma vaatepunktist tulenevalt ootuspärane. Näiteks rõhutas kuraator valdkonna spetsialistina täpse teabe tähtsust, mis isegi lihtsustatuna oli detailsem kujundajate pakutud visioonist:

Enda jaoks üks moment oli see, et mitte minna väga detailidesse, vaid katsuda anda ülevaateline pilt, aga disaineritega võib-olla kõige suuremad raskused olidki selles, et just selles ülevaatelises stsenaariumis paratamatult on detailsed momendid sees ja no vot väga ei tahtnud lasta neid detaile ... spetsialisti jaoks küsitavalt kujutada.

Agentsete tegurite seas oli kuraatoreid motiveerivaks asjaoluks neile isiklikult oluline missioon levitada teadlikkust oma valdkonnast. Demotiveerivate teguritena nimetasid nad aga oskuste, kogemuse ja motivatsiooni puudumise tunnetamist ning suurt töökoormust muude tööde kõrval.

\section{Kujuteldavad kaasamisviisid}

Põhilise kaasamisviisina nägid ekspositsiooni koostajad õpetamist, mida sõltuvalt vaatepunktist nimetati ka õppimiseks. Õpetamine oli seotud ekspositsiooni uuendamise loodus- ja keskkonnaharidusliku põhieesmärgiga, millest lähtuvalt oli tegevuste valik mitmekesine: õppeprogrammid, giidiekskursioonid, mängulised ja meelelahutuslikud tegevused, muuseumi digiarhiivide kättesaadavaks tegemine, ekspositsiooni kasutamine juhendmaterjalina (näiteks liikide määramisel). Näiteks kirjeldati, kuidas ekspositsioonis võib õppimine toimuda mänguliste tegevuste abil: 
Sa võtad väga traditsioonilise keskkonna ja nii-öelda virtuaalselt või ettekujutuslikult lood sellest teatava mänguruumi ... mis loob seoseid hoopis teiste süsteemide või struktuuride alusel kui loodusteadus näiteks ... kõiksugused osalusmängud ja teatrietendused ... Selliste asjade kõrval inimesed õnneks õpivad.

Kuraatorid kirjeldasid ka õpetamist, kus ekspositsiooni eesmärgiks on teadmiste edastamine ning auditooriumilt eeldatakse nende omandamist. Sellises nägemuses täitis ekspositsioon õppematerjali ülesannet. Kuraatori sõnul: „Me oleme selle peale mõelnud, et ta on ikkagi õpiku tugi." Samas rõhutati vajadust pakkuda õppimise kinnistamiseks aktiivtegevusi kas näiteks suunavate küsimuste või käeliste tegevuste kaudu. Õppimise ja õpetamise kaasamisviis hõlmas peaaegu kõiki auditooriume, kuid siiski mitte rahastusasutust - ometi oli seegi läbi projekti hariduslike eesmärkide seadmise õpetamisega seotud.

Üheks kaasamisviisiks oli mitmekesiste auditooriumide ning teiste kaasamisviisidega seotud huvi tekitamine, mis seisnes külastajate tähelepanu saavutamises ja hoidmises ning sellega nende ekspositsioonis käitumise suunamises soovitud viisil. Huvi tekitamise eesmärgid ja võtted sõltusid konkreetsest auditooriumirühmast, kuid oluline oli panna märkama kuraatorite esitatud materjali ja sõnumeid, aidata keskenduda, jääda meelde ning luua eeldused uuteks külastusteks. Ekspositsiooni vastu huvi tekitamiseks vajalike omadustena nimetasid kuraatorid visuaalset efektsust ja tähendusrikkaid eksponaate, hämmastust tekitavaid ning küsimustele vastuste otsimist motiveerivaid detaile, nauditavat ja esteetilist ruumi, emotsioonide käivitamist ning erinevate modaalsustega ekspositsiooni kihistusi. Huvi tekitamise kaasamisviis on suunatud kõigile auditooriumidele ning iseloomustab kuraatorite ideaali igaühele huvipakkuvast ekspositsioonist. Näiteks väljendati huvi tekitamise olulisust tekstide puhul:

Kui sa kirjutad teksti, siis sul on ees ainult üks tekst ja sul tekib justkui tunne, et sa tahaksid kirjutada sellise ilusa põhjaliku teksti ja ideaalne lugeja loeb seda, mõtleb selle üle ja kuidagi muutub nagu targemaks, aga reaalselt tähendab see seda ... et kui selles tekstis kahe sekundi jooksul inimest miski ei puuduta, siis tõenäoliselt ta ei loe seda lihtsalt.

Koostöö tegemisena määratlesime kaasamisviisi, mille puhul publik lisaks kasusaamisele panustab loodud tingimustes ka ise muuseumi vajaduste rahuldamisse. Püsiekspositsioonil on selle kaasamisviisi 
võimalused piiratud, kuid näiteks mainiti väliseksperte, kes saavad aidata määrata eksponeeritud liike organismirühmades, milles Eestis spetsialiste ei ole, ning loodusvaatluste andmebaaside integreerimist ekspositsiooniga - see võimaldab tekitada silla harrastusteadusega (nimetatud ka kodanikuteaduseks, inglise keeles Citizen Science) ning külastajad saavad ekspositsiooni külastades vahetu andmetega panustamise kogemuse:

Me oleme mõelnud siin paari varianti veel, et tegelikult ideaalis näiteks ... tuleb grupp, klass, grupp õpilasi, miks mitte täiskasvanuid, et kes näiteks kuskil õues või, ühesõnaga, kas enne või pärast selle käigu jooksul saab näiteks ise teha loodusvaatlusi ja näha, kuidas need sinna kaardirakenduse peale ilmuvad. Ehk siis sellist vahetut kogemust.

Sidusrühmade teenimise kaasamisviisile on iseloomulikud sidusrühmade vajadustest lähtuvad tegevused, näiteks saab muuseum vajadusel pakkuda ülikooli külalistele giidiekskursioone, anda sündmuste korraldamiseks inspireeriva ruumi või korraldada tegevusi uute tudengikandidaatide leidmiseks. Kui muuseum teenib koolide huve õppekavasid toetavate programmidega, siis koostööpartneritele vajalike rollide täitmise näiteks võib nimetada ekspositsiooni loomist tervikuna, mis muu hulgas teenis riikliku keskkonnahariduse edendamise arengukavas seatud eesmärke. Sidusrühmade teenimise kaasamisviisis nägid kuraatorid ka teenuste pakkumist, millel võis olla vastastikku rahalise kasu teenimise aspekt:

Seda on küll märgata, et õppeklasside kasutamine on suht aktiivne mitmesugustel muudel teemadel, mis neil endal on. Kas seminaridel või ürituste korraldamisel lisandub siis giidiekskursioon või muuseumiharidus. Võib ka olla õppeprogrammi mõttes, aga võib ka olla giidindus, noh, lihtsalt sellise külastuse mõttes ... Seda võib ka muidugi arendada, ma arvan. Rohkem proovida suunata, kellegagi koostööd teha. Selliste suurte konverentsidega võib-olla.

Sidusrühmade teenimise auditooriumina kujutleti ülikooli, ekspositsiooni loomist rahastanud asutust, koole, koostööpartnereid või nende võrgustikke ja konverentside korraldajaid.

\section{Diskussioon ja järeldused}

Meie uurimus, milles kasutasime uudse lahendusena põhiliselt sotsiaalmeedia kontekstis loodud kujuteldavate auditooriumide 
kontseptsiooni (Litt 2012), täiendab teadmisi auditooriumide kujundamise protsessist muuseumi püsiekspositsiooni koostamisel. Auditooriumide kujutlemist mõjutavate tegurite osas tugineb meie lähenemisviis Giddensi strukturatsiooniteooriale (1984), mille järgi mõjutavad auditooriumide kujutlemist struktuursed ja agentsed tegurid ning lisaks meie poolt mudelisse lisatud auditooriumidega seostatavad kaasamisviisid.

Kuna ekspositsiooni koostamise ajal silmas peetud auditooriumidest lähtuvad otsused avalduvad loodavas ekspositsioonis ja see hakkab kujundama tegelikke auditooriume, on meie lähenemisviis lisaks kontseptuaalsele edasiarendusele ka otseselt rakenduslik. Auditooriumide kujutlemist mõjutavatele teguritele tähelepanu pööramine võimaldab ekspositsiooni koostamisel läbipaistvamalt argumenteerida ühest või teisest tegurist tulenevate probleemide arutamisel, kus ettepanekud võivad olla omavahel kooskõlas, aga ka vastuolus. Näiteks võib olla tavapärane olukord, mille puhul ruumilised või finantsilised tingimused satuvad konflikti kuraatorite taotlustega, vastuolud võivad tekkida ka kuraatorite nägemuste vahel. Kuidas sel juhul saavutada tasakaal ja eesmärkide täitmine? Teadvustatud vaatenurk auditooriumide kujundamiseks on heaks abiks, kui piirangud ja pingeväljad on esitanud kuraatoritele heas mõttes väljakutse oma oskuste loovaks kasutamiseks.

Oma töös uurisime, kelles Tartu Ülikooli loodusmuuseumi ekspositsiooni koostajad auditooriume nägid. Üldistatult võib öelda, et auditooriumidena kujutleti kas isikuid või organisatsioone. Isikutest auditooriumide kategooriatena märgiti omavahel kombineeruvaid isikulisi omadusi, mille juures peeti oluliseks demograafilisi tunnuseid, erinevaid huvisid ja infotarbimise eelistusi, aga kirjeldati ka Falki (2011) välja toodud motivatsioone muuseumiga suhestumiseks. Auditooriumirühmade isikuliste omadustega kombineerub nende (näiteks õpilase või professionaali) roll.

Meie uuritud juhtumil olid organisatsioonidest auditooriumide seas koolid, ülikoolid ja ekspositsiooni rahastamist korraldav asutus. Organisatsioonid mõjutavad koostamist vajaduste kaudu, mida neile omistatakse, kuid mõnel neist võib olla mõjukus ise määratleda kohustuslikke auditooriume ning neile ette nähtud kaasamisviise. Sellised organisatsioonid olid meie näite puhul rahastamist vahendav asutus, aga ka ülikool. Nende roll auditooriumide ja kaasamisviiside kujundajatena haakub struktuursete teguritega reeglite ja ressurssidega. Kuna muuseumi ekspositsiooni valmimine on ressursimahukas, võib institutsionaalsete auditooriumide kontrolliv moment olla eriti oluline ning tugevam indiviidide huvidest ja vajadustest, mida tavapäraselt kujuteldavate auditooriumide puhul silmas peetakse. 
Alahinnata ei saa auditooriumide kujunemist mõjutavaid agentseid tegureid: kui sisutegijate oskused ja kogemused teevad püsiekspositsiooni tegelikkuseks, siis ekspositsiooni koostamise muudavad nauditavaks sisutegijaid motiveerivad tegurid (näiteks töörõõm ja missioon oma valdkonnas teadlikkust levitada). Kuraatorite isiklike motivaatorite hulgas on ka huvi pälvida innukate õppijate või tänulike vanemate tähelepanu. Kuna ekspositsiooni koostajate loominguline ülesanne on luua etteantud raame arvestav mitmekesine, terviklik ja sidus auditooriumide ning kaasamisviiside süsteem, on oluline, et eri rollides ekspositsiooni koostajad oleks teadlikud oma osast auditooriumide kujundamisel.

Uurimuse käigus täiendasime ja täpsustasime Lotina (2016) välja töötatud muuseumide kaasamisviiside loetelu püsiekspositsioonile spetsiifiliste kaasamisviisidega. Analüüs tõi välja, et isegi näiliselt homogeensel muuseumimaastikul võivad olla märkimisväärsed lahknevused sõnumi edastamiseks valitud kanalite vahel. Analüüsist selgus ka, et võrreldes varasema muuseumide kaasamisviiside analüüsiga (samas), mis arvestas ka tegevust sotsiaalmeedias, on püsiekspositsioonile omased kaasamisviisid nüansirohkemad, samas kui mõned kaasamisviisid kasutamist ei leia. Kui küllalt sarnased informeerimise ja õpetamise kaasamisviisid on jälgitavad eri keskkondades (nii sotsiaalmeedias kui ka füüsilises ekspositsioonis), siis turundamise kaasamisviisile on püsiekspositsiooni puhul kõige ligilähedasem meie tuvastatud huvi tekitamine - püsiekspositsiooni puhul ei ole küsimuseks inimeste kutsumine muuseumisse, vaid nende tähelepanu suunamine ja hoidmine. Seejuures on oluline, et kaasamine huvi tekitamise kaudu toimuks vastavalt auditooriumidele väga erinevate vahenditega.

Sidusrühmade teenimise kaasamisviis tuleb esile muuseumi missiooniga seotud olukordades, kus ekspositsioon on loodud kellegi teise (näiteks koolide, mille õppetööd peab ekspositsioon toetama) vajaduste täitmiseks. Kui sotsiaalmeediale on iseloomulik koostöö kaasamisviis, sest eri vormides koostööd on sellel platvormil kerge pakkuda, siis püsiekspositsioonis jäävad muuseumiga koostööle kaasamise võimalused väheseks ja nii jääb edaspidiseks vastata küsimus, kuidas saab püsiekspositsioon toimida hüppelauana koostööd kaasavatesse tegevustesse ja keskkondadesse. Ka meie uuritud juhtumil jäid mõned kaasamisviiside ideed tulevikku, sealhulgas näiteks digitaalsed vahendid. Ekspositsioonide loomisel, aga ka juba valminud ekspositsioonides tegevuste korraldamisel tasub ikka ja jälle mõelda, kas mõni kaasamisviis on jäänud tähelepanuta või ei ole märgatud võimalusi selle edendamiseks. 
Teadmised auditooriumide kujundamise protsessist on rakendatavad uute ekspositsioonide loomisel, olles olulised kõigile, kes tegelevad ekspositsioonide kui muuseumide tüüpilisima kaasamiskeskkonnaga Eestis. Vaatamata sellele, et enne ekspositsiooni koostamisele asumist on kontseptsioon ja eesmärgid läbi arutatud, jätkub auditooriumide kujundamine paljudes otsustamist vajavates detailides terve ekspositsiooni loomise aja. Sellisteks auditooriumide kaasamisega seotud põhiküsimusteks võivad olla näiteks, kas informeerida ja õpetada koos eeldatud vastustega või pigem inspireerida, tekitada ettearvamatuid küsimusi ning innustada dialoogi tekkimist muuseumi ja auditooriumi vahel. Tartu Ülikooli loodusmuuseumi ekspositsiooni koostamise kogemuse põhjal võib tõdeda, et teadmisi auditooriumide kujundamiseks ja nende kaasamiseks on vaja ka meeskonna paremaks liitmiseks auditooriumidest lähtuvate ettepanekute mõistmine suurendab kokkuvõttes nii tegelike auditooriumide kui ka tegijate rahulolu.

Meie uuringul on ka piirangud. Kuigi Tartu Ülikooli loodusmuuseum on lisaks näitustele ja õpilastele pakutavale mitteformaalsele haridustegevusele suunatud ka teadusele, on teadustöö ja -kogudega seotud veel teisi siin artiklis käsitlemata jäetud kaasamisviise - meie fookus oli eranditult püsiekspositsioonil. Kuna teadusega seotud ja laiale avalikkusele pakutavad tegevused on rohkem või vähem eraldi määratletavad muuseumitöö harud, võib just see olla põhjuseks, miks mõned püsiekspositsiooni koostajad, kes ei olnud igapäevaselt seotud muuseumi publiku- ja haridustegevustega, olid ainuüksi neilt eeldatud erialaksperdi rolli tõttu auditooriumide ja neid kaasavate tegevuste suhtes distantseeritud positsioonis.

Meie keskendusime uue püsiekspositsiooni kuraatorite silmas peetud kujutletavatele auditooriumidele, aga edaspidi võib pöörata tähelepanu ka hoopis auditooriumipoolsele vaatele, näiteks sellele, kuidas külastajad ise astuvad ekspositsiooni kaudu interaktsiooni teiste külastajatega, kes võivad olla nende jaoks kujuteldavad auditooriumid (Coghlan 2018).

Kokkuvõttes leiame, et muuseumid ja nende püsiekspositsioonid pakuvad väärtuslikku materjali auditooriumide ning kaasamisviiside kujundamise analüüsimiseks - nende protsesside parem mõistmine aitab leida võimalusi tegelike auditooriumide kaasamiseks ja paremateks otsusteks ekspositsiooni koostamise protsessis. Kuigi uute sõnumite, auditooriumide ja neile pakutavate tegevuste määratlemine on iga püsiekspositsiooni kavandamise loomulik osa, on planeeritud tegevuste ja ideede parimaks teostumiseks kasuks ekspositsiooni loomise protsessi mõistmine. 
KRISTA LEPIK (PhD) on infoteaduse lektor Tartu Ülikoolis. Tema doktoritöö (2013) käsitles kultuuriosalust ja külastajate „valitsemist“ Eesti avalikes teadmusasutustes. Tema teadushuvide seas on kommunikatsiooni ja kaasamisega seotud teemad muuseumides ja raamatukogudes.

\author{
REET MÄGI (MA) on meedia ja kommunikatsiooni \\ doktoriõppe ekstern Tartu Ülikoolis. Ta \\ töötab Tartu Ülikooli loodusmuuseumi ja \\ botaanikaaia näituste ja loodushariduse osakonna \\ juhatajana. Tema teadushuvid on muuseumide \\ kommunikatsioon ja muuseumide roll ühiskonnas.
}

\author{
PILLE PRUULMANN-VENGERFELDT (PhD) on meedia ja \\ kommunikatsiooni professor Malmö Ülikoolis \\ alates 2016. aastast ning ta on varem töötanud \\ Tartu Ülikooli meediauuringute professorina \\ (2014-2015). Teadushuvid keskenduvad \\ kultuurilisele osalusele ja kaasatusele \\ muuseumides, raamatukogudes ja avalik- \\ õiguslikus ringhäälingus. Ta on tegelenud \\ ka internetikasutuse ja uute tehnoloogiate \\ sotsiaalsete rakenduste teemadega. Ta on \\ Euroopa Kommunikatsiooniuuringute ja \\ Hariduse Assotsiatsiooni (ECREA) aktiivne liige \\ ning Euroopa meedia ja kommunikatsiooni \\ doktorisuvekooli direktor. Ta on avaldanud üle \\ saja teadustöö.
}

\title{
Kirjandus
}

Atkins, Liz ja Susan Wallace. 2012. Insider Research. - Liz Atkins (toim), Qualitative Research in Education. London: SAGE Publications, 47-64.

Charmaz, Kathy. 2014. Constructing Grounded Theory. 2nd ed. Los Angeles: SAGE Publications.

Coghlan, Rachael. 2018. 'My voice counts because I'm handsome.' Democratising the museum: the power of museum participation. - International Journal of Heritage Studies 24 (7): 795-809.
Dahlgren, Peter. 2006. Civic Participation and Practices: Beyond ‘deliberative democracy’. - Nico Carpentier, Pille Pruulmann-Vengerfeldt, Kaarle Nordenstreng, Maren Hartmann, Peeter Vihalemm, Bart Cammaerts (toim). Researching Media, Democracy and Participation. The Intellectual Work of the 2006 European Media and Communication Doctoral Summer School. Tartu: Tartu University Press, 23-34.

Falk, John F. 2011. Contextualizing Falk's Identity-Related Visitor Motivation Model. - Visitor Studies 14 (2): 141-157. 
Giddens, Anthony. 1984. The Constitution of Society: Outline of the Theory of Structuration. Berkeley: University of California Press.

Lepik, Krista, Halliki Harro-Loit, Katrin Kello, Merle Linno, Marju Selg, Judit Strömpl. 2014. Rootalu, Kadri, Veronika Kalmus, Anu Masso, Triin Vihalemm (toim). Sotsiaalse analü̈̈si meetodite ja metodoloogia õpibaas. http:// samm.ut.ee/intervjuu (viimati külastatud 24.07.2019).

Litt, Eden. 2012. Knock, knock. Who's there? The imagined audience. - Journal of Broadcasting \& Electronic Media 56 (3): 330-345.

Lotina, Linda. 2014. Osalustegevuste analüüs Läti muuseumides. - Eesti Rahva Muuseumi aastaraamat $57,76-95$.

Lotina, Linda. 2016. Conceptualizing Engagement Modes: Understanding Museum-Audience Relationships in Latvian Museums. [Doktoritöö.] Tartu: Tartu Ülikooli Kirjastus.

Lotina, Linda, Krista Lepik. 2015. Exploring engagement repertoires in social media: the museum perspective. - Journal of Ethnology and Folkloristics 9 (1): 123-142.

Marwick, Alice E., danah boyd. 2010. I tweet honestly, I tweet passionately: Twitter users, context collapse, and the imagined audience. - new media \& society 13 (1): 114-133.

Murumaa-Mengel, Maria. 2017. Managing Imagined Audiences Online: Audience Awareness as a Part of Social Media Literacies. [Doktoritöö.] Tartu: Tartu Ülikooli Kirjastus.

Muuseumide ja raamatukogude külastajate ja mittekülastajate uuringu lõpparuanne. 2018. Kantar Emor. https://www.kul.ee/sites/ kulminn/files/muuseumide_ja_raamatukogude_kulastajate_ja_mittekulastajate_uuringu_lopparuanne_o.pdf (viimati külastatud 30.04.2019).
MTM London. 2010. Digital audiences: Engagement with arts and culture online. http://www. aandbscotland.org.uk/documents/2012-05-2813-11-39-10-Digital-audiences-for-arts-andculture-november2010.pdf (viimati külastatud 30.04.2019).

Nanì, Alessandro. 2018. Cross-Media in Public Service Broadcasting: The Struggle Between Producers and Audiences. [Doktoritöö.] Tartu: Tartu Ülikooli Kirjastus.

O’Neill, Mark. 2008. Museums, professionalism and democracy. Cultural Trends 17 (4): 289-307.

Rattus, Kristel. 2016. Dialoogilisus Eesti Rahva Muuseumi püsinäitusel „Kohtumised“. - Eesti Rahva Muuseumi aastaraamat 59, 142-161.

Runnel, Pille (toim). 2014. Osalus muuseumides. Tartu: Eesti Rahva Muuseum.

Runnel, Pille, Pille Pruulmann-Vengerfeldt. 2012. Kui muuseumist saab sõnum osalevatele auditooriumidele. - Eesti Rahva Muuseumi aastaraamat $55,32-51$.

Runnel, Pille, Krista Lepik, Pille Pruulmann-Vengerfeldt. 2014. Külastajad, kasutajad, auditooriumid: inimeste kontseptualiseerimisest muuseumis. - Eesti Rahva Muuseumi aastaraamat 57, 96-115.

Smart, Pamela. 2008. Crafting aura: Art museums, audiences and engagement. - Visual Anthropology Review 16 (2): 2-24

Teppor, Marke, Agnes Aljas. 2013. Kultuuripärandi vahendajad: käsitööharratajate ja muuseumide koostöö. - Eesti Rahva Muuseumi aastaraamat 56, 70-93. 


\author{
Krista Lepik \\ Reet Mägi \\ Pille Pruulmann-Vengerfeldt
}

The article aims to enhance the understanding of audience engagement and ways of its shaping in relation to permanent expositions by using the example of Tartu University Natural History Museum. We focus on the role of exhibition curators as content creators in the shaping of audience engagement. The study is informed by constructivist grounded theory and draws upon eleven semi-structured interviews with the curators of the new permanent exhibition of Tartu University Natural History Museum. In order to understand better the curators' perspectives our analysis relies on the concept of imagined audiences and seeks to answer questions about what kind of engagement modes can be identified from the curators' comments and what processes the latter were influenced by.

The theme of museum audiences and engagement modes should already be familiar to the reader from previous Yearbooks of the Estonian
National Museum (Runnel ja Pruulmann-Vengerfeldt 2012; Runnel, Lepik, Pruulmann-Vengerfeldt 2014; Lotina 2014; Rattus 2016). Earlier discussions, however, placed more emphasis to the existence of audiences and engagement modes, and were less concerned with how curatorial considerations can impact the formation of audience engagement and how this formative process may be directed. Furthermore, the earlier in-depth identification of engagement modes and examination of the interrelationships between their various aspects was underpinned by a holistic view on museum activities (Lotina 2016), while the present treatment focuses on the specific context of museum expositions. The concept of imagined audiences (Litt 2012) draws on the study of social media, but for this article we have applied its principles to a museum exposition, which is a far more static communicative environment. 
The study answered the questions about the kind of audiences the curators who put together the permanent exhibition of Tartu University Museum of Natural History were envisioning and what factors influenced the construction of audiences as well as what engagement modes were designed for the exposition. Individuals and institutions were distinguished among the audiences, both of which were in turn comprised of more detailed groups. Building on Gidden's theory of structuration (1984) and Litt's notion of an imagined audience (Litt 2012) the factors influencing the curators were grouped as either structural or agential. The following modes of engagement with the permanent display emerged: teaching, attracting interest, co-operation and provisions for stakeholders. Teaching was closely interlinked with the main objective of renewing the permanent display: the intent is to create a learning environment for non-formal environmental education, and in this respect it resembled the informing mode of audience engagement identified by Lotina (2016). Attracting interest was a mode of engagement which bore similarities to the marketing engagement mode previously described by Lotina (2016). Co-operation where visitors contribute towards the fulfillment of the museum's objectives offered limited possibilities within the context of the permanent exhibition, but it holds considerable potential in the planning of future developments of the exposition. Providing for stakeholders was reflected in the museum's consideration of the stakeholders' needs, and it allows the museum to develop various services. All in all, both museums and their permanent displays offer valuable material for analysing the way in which audiences and their engagement modes are shaped. A better understanding of these processes will help us expand the possibilities of engaging actual audiences. Identifying messages, audiences and activities is a natural part of the planning of any permanent exhibition; however, the content creators' visions of the upcoming exhibition also merit a detailed examination, and thereby particular factors that favour or constrain curatorial creativity will become clearer. 


\section{Где начинается и проходит граница фантазии куратора? Воображаемые аудитории и способы их вовлечения при создании новой постоянной экспозиции Музея природы Тартуского университета}

\author{
Криста Лепик \\ Реэт Мяги \\ Пилле Пруульманн-Венгерфельдт
}

Цель статьи - внести вклад в понимание и формирование приёмов вовлечения аудитории на постоянных музейных экспозициях на примере Музея природы Тартуского университета. Наше внимание сосредоточено на деятельности кураторов-составителей выставок как создателей приёмов вовлечения публики. Опираясь на конструктивистскую теорию, проводится анализ одиннадцати полуструктурированных интервью с кураторами новой постоянной экспозиции Музея природы Тартуского университета. Для лучшего понимания точек зрения кураторов наш анализ опирается на концепцию воображаемых аудиторий. Мы пытаемся понять, какие приёмы вовлечения публики можно распознать по комментариям кураторов и какие процессы на них при этом повлияли.
Тема музейной публики и способов её вовлечения знакома читателю из предыдущих ежегодников Эстонского национального музея (Runnel \& Pruulmann-Vengerfeldt 2012; Runnel, Lepik, PruulmannVengerfeldt 2014; Lotina 2014; Rattus 2016). Однако в предыдущих анализах внимание обращалось скорее на наличие аудитории и способов её вовлечения, чем на то, как рождаются соображения, влияющие на их формирование, и каким образом можно управлять этим процессом. Кроме того, приёмы вовлечения и взаимосвязь между связанными с ними аспектами до этого определялись через холистический взгляд на деятельность музеев (Lotina 2016), тогда как в нашем анализе - на специфический контекст выставок. Концепция воображаемых аудиторий (Litt 2012) основывается на изучении 
соцсетей. Мы применяем её принципы к экспозициям как намного более статичной коммуникативной среде.

Результаты исследования дали ответы на следующие вопросы: какую публику представляли кураторы в процессе создания новой постоянной экспозиции Музея природы Тартуского университета, какие факторы повлияли на конструирование целевой аудитории, какие приёмы вовлечения публики были разработаны для выставки? Целевая аудитория разделилась на индивидов и учреждения, состоящие, в свою очередь, из групп поменьше. Факторы, повлиявшие на кураторов, были разделены на структурные и агентные, согласно теории структурации Гидденса (1984) и концепции воображаемых аудиторий Литта (2012). Также были выявлены следующие приёмы вовлечения публики: обучение, пробуждение интереса, сотрудничество, обслуживание партнёров, причастных к деятельности музея. Обучение было тесно связано с основной целью обновления экспозиции - создание среды обучения для неформального образования в сфере окружающей среды, что схоже со способом вовлечения путём информирования у Л. Лотиной (2016). Пробуждение интереса было способом вовлечения, имеющим схожие признаки с ранее описанным маркетинговым способом вовлечения (Lotina 2016). Сотрудничество, в ходе которого посетители содействуют достижению целей музея, имело ограниченные возможности в контексте постоянной экспозиции, но большой потенциал при планировании развития уже после открытия выставки. Обслуживание партнёров музея выражалось в удовлетворении потребностей партнёров, что даёт возможность для развития разнообразных услуг.

Итак, как музеи, так и их постоянные экспозиции обладают ценным материалом для анализа формирования целевых аудиторий и способов их вовлечения. Лучшее понимание этих процессов поможет поиску разнообразных возможностей для вовлечения реальных аудиторий. Определение месседжей, целевых аудиторий и предлагаемых им занятий является естественной частью планирования любой постоянной экспозиции. При этом представления составителей о готовящейся экспозиции заслуживают углублённого рассмотрения в целях выяснения обстоятельств, благоприятствующих или ограничивающих творчество кураторов. 